\title{
Edmunda Millera poezja eksperymentu. Między futuryzmem i konstruktywizmem
}

Sławomir Sobieraj

TEKSTY DRUGIE 2020, NR 5, S. 295-310

DOI: 10.18318/td.2020.5.18 | ORCID: 0000-0001-6332-692X

$\mathbf{P}$ rzez długie lata w pracach literaturoznawczych dotyczących okresu międzywojennego trudno było natrafić na jakiekolwiek informacje o dorobku pisarskim Edmunda Millera. Jedynie Elżbieta Rybicka w ostatnim ćwierćwieczu przypomniała jego powieść Fikcyjna postać", zajmując się problematyką miejską we współczesnej prozie polskiej². Sporadyczne wzmianki o tym twórcy pojawiały się już wcześniej, ale najczęściej w powiązaniu z opisem działań awangardowych w sztukach plastycznych, a nie w odniesieniu do aktywności literackiej. Między innymi Zofia Baranowska przywoływała jego współpracę z redakcją pisma „Blok”3 oraz autorstwo wstępu

1 E. Miller Fikcyjna postać. Powieść, Towarzystwo Wydawnicze "Rój”, Warszawa 1934.

2 E. Rybicka Obrazki z ulicy. O «Fikcyjnej postaci» Edmunda Millera, „Teksty Drugie" 1999 nr 4, s. 137-153; tejże Modernizowanie miasta. Zarys problematyki urbanizacyjnej w nowoczesnej literaturze polskiej, Universitas, Kraków 2003, s. 209-212.

3 "Blok" (podtytuł: „Czasopismo awangardy artystycznej") wydawano w latach 1924-1926; ukazało się osiem zeszytów. Pismo było redagowane przez Henryka Stażewskiego, Teresę Żarnowerównę, Mieczy-
Sławomir Sobieraj

- profesor uczelni w Instytucie Językoznawstwa i Literaturoznawstwa UPH w Siedlcach. Zajmuje się głównie badaniem poezji awangardowej, a także twórczości Tadeusza Micińskiego. Zainteresowany również pisarstwem związanym z Mazurami. Autor monografii: Awangarda mniej znana.Przypadki poezji (2018), Laboratorium awangardy. O twórczości literackiej Tytusa Czyżewskiego (2009), Alchemia wyobraźni. Rezonans twórczości Tadeusza Micińskiego w poezji międzywojennej (2002). 
do katalogu wystawy Mieczysława Szczuki, zaś tylko zdawkowe informacje zamieszczone zostały w monografii Andrzeja Lama poświęconej awangardzie poetyckiej ${ }^{5}$ i w szkicu Krystyny Sierockiej o czasopismach literackich dwudziestolecia ${ }^{6}$.

Nie znajdziemy danych biograficznych tego awangardowego artysty w żadnym z leksykonów pisarzy bądź w słowniku biograficznym. Minibiogramy zredagowane przez badaczy sztuki filmowej ${ }^{7}$ i literatury ${ }^{8}$ nie podają nawet dokładnych dat jego życia. Edmund Miller (1899-1969) ${ }^{9}$ był poetą i prozaikiem, także publicystą, który zajmował się zagadnieniami literatury i sztuki. W latach międzywojennych wypowiedzi krytyczne publikował w „Epoce”,,Bloku”,, Głosie Literackim”,,Wieku XX”,,Grafice” i „Plastyce”.Jako poeta znany jest z kilku wierszy zamieszczonych w piśmie konstruktywistów, jako prozaik z powieści Fikcyjna postać, która spotkała się z niejednoznaczną opinią krytyków ${ }^{10}$. W latach 30. ogłosił drukiem ponadto nowelę $W$ drewniaku na Moskiewskiej oraz dwa drobiazgi prozą ${ }^{11}$.Zaraz po wojnie ukazała się druga powieść pisarza - Świta jużzaranie ${ }^{12}$.

sława Szczukę i Edmunda Millera. Miller i Stażewski ustąpili z redakcji po wydaniu trzeciego zeszytu (nr 3-4).

4 Z. Baranowicz Polska awangarda artystyczna 1918-1939, Wydawnictwa Artystyczne i Filmowe, Warszawa 1979, s. 78, 99.

5 A. Lam Polska awangarda poetycka. Programy lat 1917-1923, t. 1: Instynkt i ład, Wydawnictwo Literackie, Kraków 1969, s. 161.

6 K. Sierocka Czasopisma literackie, w: Literatura polska 1918-1975, t. 1: Literatura polska 1918-1932, red. A. Brodzka, H. Zaworska, S. Żółkiewski, Wiedza Powszechna, Warszawa 1975, s. 101.

7 Zob. M. Giżycki Walka o film artystyczny w międzywojennej Polsce, PWN, Warszawa 1989, s. 46.

8 Zob. K. Jaworski Kronika polskiego futuryzmu, Wydawnictwo UJK w Kielcach, Kielce 2015, s. 582.

9 Wiarygodne informacje o datach urodzin i śmierci twórcy, ustalone na podstawie relacji jego syna, odnotowała J. Kulczycka-Saloni. Zob. Spis zawartości archiwum Janiny Kulczyckiej-Saloni, oprac. G.P. Bąbiak, D. Dziurzyński, Wydział Polonistyki UW, Warszawa 2000, s. 35.

E. Czekalski Miller Edmund: Fikcyjna postać. Powieść. Warszawa, 1934. Str. 294. Tow. Wyd. „Rój”, "Nowa Książka" 1934 nr 3, s. 124. Recenzent pisze m.in. o „zręczności pisarskiej” autora, dostrzega w utworze echo kawiarnianego życia warszawskiej inteligencji. Mniej przychylnie wypowiada się o powieści Leon Piwiński, wzmiankując o tematyce robotniczej i „mgławicowym” ujęciu zagadnienia (L. Piwiński Powieść, „Rocznik Literacki za rok 1934”, s. 108-109).

11 E. Miller Miniatury, „Pion” 1934 nr 26, s. 3. Pod wspólnym tytułem kryją się dwa osobne teksty: Wspomnienie i Scherzo. 
Edmund Miller na przełomie pierwszej i drugiej dekady XX wieku należał do kręgu towarzyskiego studentów warszawskiej Szkoły Sztuk Pięknych, którzy później stworzyli polski nurt konstruktywizmu. Uczestniczył w spotkaniach artystów i pisarzy, podczas których dyskutowano o koncepcjach nowej sztuki: formizmie, ekspresjonizmie i futuryzmie ${ }^{13}$. Przyjaźń ze Szczuką zaowocowała napisaniem przez Millera wstępu do wystawy kolegi. Była to prawdopodobnie pierwsza jego wypowiedź publiczna, która została odnotowana przez krytyków sztuki. Niewątpliwie przyczyniły się do tego szokująca treść i forma tekstu, zapisanego fonetycznie, w myśl idei, którą Marinetti określał wyrażeniem: „zuchwałość oryginalności”. Pismo fonetyczne można też potraktować jako nawiązanie do hasła włoskiego twórcy: odrzucania starych zużytych form ${ }^{14}$.

Wystawa obrazów i grafik Mieczysława Szczuki odbywała się w Warszawie, w salach Polskiego Klubu Artystycznego w okresie od 23 maja do 30 czerwca 1920 roku. Spotkała się z zainteresowaniem miłośników sztuki i prasy codziennej, która donosiła o oburzającym potraktowaniu przez artystę tematyki religijnej oraz lekceważeniu zasad współczesnego malarstwa, choć jeden z krytyków dostrzegał w pracach Szczuki nieprzeciętny talent ${ }^{15}$. Nie mniejsze kontrowersje wzbudził tekst Millera w katalogu wystawy ${ }^{16}$. Dziennikarz „Gońca Krakowskiego” zauważał jego nieortograficzność i z ironią zaliczał do nurtu nowych form w sztuce ${ }^{17}$. Niezaprzeczalnie tekst wpisywał się w stylistykę manifestów futurystów, a doszukiwać się w nim można akcentów dadaistycznych i ekspresjonistycznych, jak czyni Andrzej Turowski w monografii konstruktywizmu polskiego ${ }^{18}$.

Natomiast Krzysztof Jaworski przedstawia kilka argumentów przemawiających za futuryzmem tej wypowiedzi. Szerzej omawia zagadnienie

13 A. Turowski Konstruktywizm polski. Próba rekonstrukcji nurtu (1918-1934), Ossolineum, Wrocław 1981 , S. 24-25.

Por. C. Baumgarth Futuryzm, przeł. J. Tasarski, Wydawnictwa Artystyczne i Filmowe, Warszawa 1978, s. 56, 232.

15 Pisze o tym Krzysztof Jaworski w artykule: Katalog wystawy Mieczysława Szczuki - zapomniany manifest futurystyczny z 1920 roku , "Przegląd Humanistyczny” 2008 nr 4, s. 120-122.

16 E.M. [Edmund Miller] Katalok wystawy Szczuki. Warszawa maj-czerwiec 1920, Warszawa [1920]. Wszystkie cytaty tekstu podaję według tego źródła. (m - m) Nieortograficzny katalog a "nowe dreszcze", ,Goniec Krakowski" 1920 nr 156, s. 5.

18 Por. A. Turowski Konstruktywizm polski..., s. 32-33. Badacz twierdzi, że zarówno Szczuka, jak i Miller pozostawali wówczas bardziej pod wpływem ekspresjonizmu, z „nikłymi naleciałościami dadaizmu czy futuryzmu". 
uproszczonej pisowni, opisując praktyki Millera w kontekście podobnych eksperymentów językowych w utworach Jerzego Jankowskiego i Brunona Jasieńskiego. Ponadto dostrzega związki z działalnością Marinettiego w stosowaniu poetyki manifestu „negatywnego” oraz głoszeniu haseł zerwania z przeszłością. Doszukuje się również elementów dadaizmu' ${ }^{19}$. Tytułem uzupełnienia warto zwrócić uwagę na występujące w tym tekście inne powinowactwa z futuryzmem: nastawienie na przyszłość, łamanie kanonów dawnej sztuki i wiarę w geniusz człowieka.

Niewątpliwie istotne w kwestii ustalenia futurystycznego rodowodu manifestu jest wskazanie Jaworskiego na zasadę zapisu fonetycznego. Niedługo przed ukazaniem się katalogu wystawy Szczuki żywo dyskutowana w środowisku literatów była sprawa skandalizującej ortografii w tomie Jankowskiego Tram wpopszek ulicy. Wilam Horzyca twierdził, że oryginalna pisownia nie jest tylko „krzykliwą demonstracją futuryzmu”, ale istotnym określeniem idei przyświecającej celom artystycznym poety. Odczytując w żywiołowym zwrocie ku nieuczoności jej waloryzację, widział w nim również przejaw pierwotności ${ }^{20}$ oraz zauważał związki z koncepcją powrotu do natury Jeana-Jacques'a Rousseau ${ }^{21}$. Nagłośnienie skandalizujących wystąpień przedstawicieli nowej sztuki, a także komentarze, z jakimi się spotkał wspomniany zbiór wierszy, stanowiły zapewne inspirację dla autora Kataloku.

Wydaje się, że mógł być nią również tom prozy poetyckiej Aleksandra Wata, bowiem analizowany tekst Millera zawiera w sobie wiele elementów poetyckości. Metafora goni metaforę, a skojarzenia są zazwyczaj zaskakujące. Oto kila przykładów: „Wodwiecznym ruchu ktury wyparował z abecadła tajemnic człowiek się dzieje i krzyczy o wolność,,,,jednak tetamteowe definicje są tylko niemowlęcym bełkotem o wewnącz kłębiącym się nienazwanym o tym motoże ruhuf tszepoczącyh rąk ranionego człowieka”, „Naelektryzowany them oczekiwań kszyk wolności słania się w obliczu tęsknoty". Odczytując ostatnią z przytoczonych fraz, nie sposób oprzeć się wrażeniu, że jest spowinowacona z pierwszym zdaniem Watowskiego Piecyka, w którym podobnie dochodzi do personifikacji rzeczownika abstrakcyjnego: „Szczęście

K. Jaworski Katalog wystawy Mieczysława Szczuki..., s. 126.

Ową pierwotność należałoby interpretować także jako przejaw prymitywizmu, który pojawił się nie tylko w programach i twórczości futurystów włoskich i rosyjskich, ale też polskich.

W. Horzyca Yeży Yankowski, Tram wpopszek ulicy. Warszawa, Wydawnictwo Futuryzm Polski, 1920, "Skamander" 1920 t. 1, z. 1, s. 47-48. 
szwenda się za nami bezradosne istotne konieczne i złote"22. Nagromadzenie dużej ilości motywów kulturowych, występujących w opisie drogi twórczej współczesnego artysty (Edypa), który w swojej wędrówce przez wieki od czasów Asyrii i Babilonu zmierza ku teraźniejszości znaczonej „nocnym szeptem miast" i duchem motoru, mocno przypomina synkretyzm Wata, jego tendencję do mieszania znaków kultury ${ }^{23}$.

W tekście dominują zdania wielokrotnie złożone, które układają się w potok myśli wypowiadanych jakby w transie. Językowe skomplikowanie wynika też z braku znaków przestankowych, a z rzadka występujące duże litery sygnalizują początki dłuższych konstrukcji syntaktycznych bądź słowa i zagadnienia szczególnie ważne dla autora: Sztuka, Artysta, Edyp (figura człowieka tragicznego).

Wypowiedź ma cechy właściwe zarówno dla manifestu, jak i dla tekstu artystycznego, tj. prozy poetyckiej. Jej pierwsze słowa - rozpoczynające wywód o współczesnej sztuce - mogłyby posłużyć za wymowny tytuł: „Pszecif kostnieniu fformach znalezionych". Kolejna część katalogu zawiera anegdotyczną biografię Mieczysława Szczuki (tu fragment zapisany w formie wiersza), a trzecie ogniwo prowokacyjnie banalną minikonstatację na temat twórczości: „O obrazach Szczuki powiedzieć się da popiersze że są pszekonywujące”. Część czwarta - czyli krótkie zamknięcie - wyraża lekceważenie reguł stylu wysokiego i poważnego traktowania sztuki: „Koniec końcuf koniec".

Do kolejnego zaistnienia Edmunda Millera w świecie artystów doszło w grudniu 1921 roku podczas wspólnej wystawy z Mieczysławem Szczuką i Henrykiem Stażewskim. Było to jednak wystąpienie na drugim planie; o pracach poety niektórzy komentatorzy nawet nie wspominali ${ }^{24}$. W relacji Władysława Skoczylasa w ogóle nie zostały wymienione nazwiska, mowa tylko o młodych i „bezwzględnie utalentowanych” artystach, którzy jednakże przedstawiają dzieła małowartościowe, korzystając z „nieznanych znaków konwencjonalnych" i naśladując obce wzory ${ }^{25}$. Wobec tego, że nie

22 A. Wat /A z jednej strony i /A z drugiej strony mego mopsożelaznego piecyka, w: tegoż Poezje zebrane, oprac. A. Micińska i J. Zieliński, Wydawnictwo Znak, Kraków 1992, s. 115.

Zob. S. Sobieraj Alchemia wyobraźni. Rezonans twórczości Tadeusza Micińskiego w poezji międzywojennej, Wydawnictwo Akademii Podlaskiej, Siedlce 2002, s. 51. 
zachowały się żadne prace z tej wystawy ani jej katalog ${ }^{26}$, jedynie ogólnikowe wyobrażenie o nich daje recenzja Jana Nałęcza-Lipki, który pisał o związkach twórczości Szczuki z nowymi kierunkami w sztuce: tatlizmem, dadaizmem i suprematyzmem, Stażewskiego - z formizmem, natomiast w odniesieniu do autora Fikcyjnej postaci odnotowywał nowatorstwo stosowanych środków:

Poeta Miller (Edmund) wystawił plakaty, gdzie za pomocą przestankowania, grupowania i pisania większymi lub mniejszymi znakami zaakcentować chce sens wewnętrzny wyrazów. Również dla silniejszej ekspresji i znaczenia symbolicznego stosunku zdań używa różnych barw. ${ }^{27}$

Treść tego zwięzłego omówienia pozwala domyślać się, że obiekty wystawione przez Millera miały cechy werbalno-plastyczno-foniczne, że mogły to być „prace w duchu poezji wizualnej", jak pisze jeden z badaczy ${ }^{28}$, ale też nie pozbawione wartości dźwiękowej.

Wymienione wyżej cechy dałoby się przypisać utworom poetyckim publikowanym w piśmie konstruktywistów na początku 1924 roku. Spośród czterech zamieszczonych tam wierszy Millera jeden szczególnie przypomina dzieło plastyczne. „RLIR...” to układ 42. wersów (bez tytułu), zapisanych wersalikowo, z których najdłuższy składa się z pięciu liter. Litery nie tworzą wyrazów notowanych przez słowniki języka polskiego, czasami jedynie je przypominają z powodu podobnego brzmienia:

\section{PROPL}

\section{TRAM}

MOTR $^{29}$

Można je kojarzyć ze słowami uznawanymi za emblematy poezji futurystycznej: propeller (śmigło samolotu), tramwaj, motor. Traktując wiersz jako zagadkę o konstrukcji szarady, ze zbitek liter zgromadzonych w pierwszych trzech wersach można wyczytać nazwisko autora. Aspekt ludyczny wpisany

\footnotetext{
26 Por. A. Turowski Konstruktywizm polski..., s. 34.

J.L. [Jan Nałęcz-Lipka] Wystawa Szczuki, Starżewskiego, Millera, "Lucifer” 1922 nr 2-4, S. 34.

M. Giżycki Walka o film artystyczny w międzywojennej Polsce..., s. 46. 
w tekst wskazuje na powinowactwo z praktykami dadaistów, ich abstrakcyjnymi wierszami fonetycznymi, np. Hugona Balla i Raoula Hausmanna ${ }^{30}$. Ponadto zestawienia liter-głosek dają efekt w postaci przekazu swoistego nastroju.

Analogicznie, choć nieco mniej radykalnie, eksperymentował na początku lat 20. w niektórych wierszach Aleksander Wat. Trop wiedzie od dadaizmu w stronę konstruktywizmu i poezji konkretnej. Należy uwzględnić to, że Miller obracał się w kręgu artystów współtworzących polski konstruktywizm, mających udział w rozwoju fotomontażu i druku funkcjonalnego. Na konstruktywistyczny wymiar analizowanego utworu składają się: zmienny krój czcionek, ich barwa (wypełnione czarne i obramowane „białe”, nieco węższe), także ich zróżnicowana wielkość - ostatnie dwa wersy to powtarzająca się i kilkakrotnie powiększona na różne sposoby litera „u”. Poza tym możliwe jest odczytywanie tekstu jako poezji konkretnej, którą cechuje aneksja tworzywa uznanego tradycyjnie za plastyczne. Tego rodzaju praktyki miały jedno ze swoich źródeł w dziełach kubistów (najpierw malarzy, później poetów), a skutkowały twórczością z pogranicza sztuk, jak np. fotomontaże i plakaty ${ }^{31}$. Można przypuszczać, że „RLIR...” to jeden z plakatów prezentowanych przez artystę kilka lat wcześniej na wspólnej wystawie ze Szczuką i Stażewskim.

Równie eksperymentalny charakter ma inny utwór bez tytułu Edmunda Millera („O most wrębliwie...”), który zaskakiwał sposobem druku naśladującym odręczne pismo. W tym wypadku mamy do czynienia także z niespodzianką w aspekcie wizualnym. To zapis języka semantycznie wyabstrahowanego w formie graficznej, odbiegającej od norm powszechnie przyjętych w wydawnictwach drukowanych, również ze względu na dosunięcie do lewej krawędzi strony:

o most wrębliwie radioakty trą się

i w transie mechanicznym krwi

dzwonią stance stań się

miłosny głód żre łona maszyn w pąsopląsie

wy cyrklem cyrk na cytrach wyekrańcie

Por. H. Richter Dadaizm. Sztuka i antysztuka, przeł. J.St. Buras, Wydawnictwa Artystyczne i Filmowe, Warszawa 1983, s. 63-64, 203.

31 Zob. G. Gazda Poezja konkretna a problemy awangardy, w: The Structure and Semantics of the Literary Text, ed. by M. Péter, Akadémiai Kiadó, Budapest 1977, s. 53. 
rozwiosennijcie trust automatycznych szałów elektrobiodrych drgań algebra ustom sens śle mostowy łuk napina prężne ciała i dreszczem pachwin pachną gęśle w przęśle. ${ }^{32}$

Treść wskazuje na tematykę popularną w liryce awangardowej, związaną z przekraczaniem tabu, którym jest tutaj wątek miłości fizycznej. Erotyczny wymiar utworu poświadczają wyrażenia opisowe: "prężne ciała” i „dreszcz pachwin”. Miłosny szał został nazwany „transem mechanicznym”. Szukanie odpowiedników doświadczeń uczuciowo-fizjologicznych w leksyce wywodzącej się ze sfery techniki („mechaniczny”, „maszyna”, „ekran”, ,automatyczny”, ,elektryczność”, „przęsło") koresponduje nie tylko z ideą opiewania piękna najnowszych wynalazków i widzenia ludzkiego ciała jako niezwykłej biologicznej maszyny (co charakterystyczne u futurystów), ale też wydaje się mieć związek z koncepcją metafory Tadeusza Peipera, który przedstawiał ją następująco:

Metafora, zbudowana na pojęciach odległych, daje poezji urojoną perspektywę [...]. Rzeczy odświętne lub święte zestawia się z rzeczami codziennymi i pospolitymi, rzeczy codzienne przenosi się między pojęcia uroczyste i uświęcone. Przedmioty widziane niechętnie, pochodzące z tych dziedzin świata i życia, od których odwraca się wrażliwość estetyczna przeciętnego człowieka, amalgamuje się z przedmiotami o rezonansach uczuciowych, silnie ugruntowanych w człowieku. ${ }^{33}$

Miller dostosowuje się do zaleceń Peipera, łączy świat techniki ze światem pieśni miłosnej, do czego odsyła słowo „stanca”. Najwyrazistszym przykładem owej praktyki łączenia oddaleń semantycznych jest mocno zmetaforyzowana fraza: „miłosny głód żre łona maszyn w pąsopląsie”. Poza tym w wyrażeniu "mostowy łuk" można widzieć analogię do łuku ciał spiętych w miłosnym uniesieniu.

E. Miller "O most wrębliwie..." [właśc. bez tytułu] „Blok” 1924 nr 2, s. 4. W cytacie uwspółcześniono pisownię wyrazów niektórych wyrazów: "stance" i "pąsopląsie” (w oryginale: "stanze $\mathrm{i}$ "ponsopląsie").

33 T. Peiper Metafora teraźniejszości, w: tegoż, Tędy. Nowe usta, oprac. S. Jaworski, T. Podoska, Wydawnictwo Literackie, Kraków 1972, s. 56-57. 
W wierszu występuje wiele neologizmów, które są zjawiskiem typowym dla udziwnień wczesnej poezji futurystycznej w Polsce: „wrębliwie”, „radioakty" ${ }^{\prime 34}$, ,pąsopląsy”,,wyekranić”, ,rozwiosennić”,,,elektrobiodre”.Już same ich walory brzmieniowe są dowodem innowacyjności języka, a zarazem nastawienia ich autora na zaskoczenie odbiorcy. Ponadto można pokusić się o postawienie tezy, że dźwiękowość ma duży wpływ na kompozycję i sens utworu. To jeszcze jeden dowód na jego związki z poetyką futuryzmu, która w polskiej wersji przybierała niekiedy formułę konceptyzmu foniczno-znaczeniowego ${ }^{35}$.

Niektóre zestawienia wyrazów, których następstwo wynika z podobieństwa brzmienia, przywodzą na myśl namopaniki Wata oraz z wierszami Jasieńskiego: Na rzece czy Wiosenno. W pierwszym z wymienionych podmiot liryczny to bawiący się słowem homo ludens ${ }^{36}$. Gra semantyczna u Millera polega na uszeregowaniu obok siebie słów fonicznie podobnych, ale semantycznie i kulturowo odległych, także frazeologicznie niełącznych, co ilustruje absurdalny wers: „wy cyrklem cyrk na cytrach wyekrańcie”. Również rymowanie uwikłane jest w ową grę semantyczną, zwłaszcza w końcowym układzie, gdy wyrażenie „gęśle w przęśle" narusza estetyczne przyzwyczajenia czytelnika, ewokując jednocześnie korespondencję różnych zjawisk: fizycznego tarcia o siebie ciał, przeciagania smyczka po strunach dawnego prymitywnego instrumentu, a także pracy przęsła mostu pod naciskiem przejeżdżających po nim pojazdów.

Eksperymentom fonostylistycznym towarzyszyły w wierszach Millera innowacje słowno-plastyczne. Dwa utwory: Stara historia i Zielony koncert mieszczą się w pełni w konwencji poezji wizualnej, której w polskich badaniach literaturoznawczych, zwłaszcza w odniesieniu do literatury XIX i XX wieku, nie poświęcono zbyt wiele uwagi ${ }^{37}$. W najobszerniejszym opracowaniu

34 "Radioakty" nie określają tu treści nadawanych przez radio. Na początku lat 20. używano u nas słowa "radiofon", a rozgłośnie radiowe w Polsce jeszcze nie istniały. Cząstka "radio-" (pochodząca od łacińskiego "radius" - promień) mogła być odczytywana wówczas jako oznaczenie promieniowania uczuć bądź ciał.

Zob. B. Śniecikowska „Nuż w uhu?”. Koncepcje dźwięku w poezji polskiego futuryzmu, Wydawnictwo Naukowe UMK, Toruń 2017, s. 477-478.

E. Balcerzan Styl i poetyka twórczości dwujęzycznej Brunona Jasieńskiego, Ossolineum, Wrocław 1968 , s. 66. chu, Warszawa 1989 (tu tylko rozdział omawiający twórczość artystów wieku 20.), monografia B. Śniecikowskiej Słowo - obraz - dźwięk. Literatura i sztuki wizualne w koncepcjach polskiej awangardy 1918-1939, Universitas, Kraków 2005 (tylko dwie pierwsze części) oraz dwa rekone- 
Piotra Rypsona Obraz stowa. Historia poezji wizualnej odnotowano, co prawda, Edmunda Millera jako autora „eksperymentalnych układów literowych”, nie przywołano jednakże żadnego z jego utworów ${ }^{38}$.

W pierwszej połowie lat 20. w pismach kulturalno-artystycznych w Polsce zaczęły pojawiać się wiersze zadziwiające uniezwykloną typografią oraz swobodnym, nietradycyjnym rozmieszczeniem wersów bądź słów na stronie, uzupełniane niekiedy znakami ikonicznymi. Coraz częściej koegzystencja słowa i obrazu stawała się środkiem wyrazu u poetów nowej sztuki, którzy inspirowali się twórczością Apollinaire'a i Marinettiego. Edmundowi Millerowi, który obracał się w kręgach artystów awangardowych, nie mogła być obca eksperymentalna liryka Czyżewskiego (np. Mechaniczny ogród i Hamlet w piwnicy) czy Sterna (romas peru). W przywołanych utworach nietypowa kompozycja układu przestrzennego wykracza poza uświęcone tradycją literacką reguły, łamie nie tylko porządek linearny, ale też składniowy i przyczynowo-skutkowy. Wyraża się w technice montażowej operującej niejednorodnym tworzywem ${ }^{39}$.

Prawdopodobnie to Edmund Miller, jako redaktor odpowiedzialny w „Bloku" za sprawy literackie, miał wpływ na zamieszczenie w zeszycie nr 3-4 thumaczenia wiersza francuskiego poety futurysty Nicolasa Beauduina Miasto we mnie. Przypuszczenie wynika z podobieństwa do tego tekstu, pod względem treści i formy, drukowanych kilka stron dalej utworów poetyckich polskiego autora. W przypadku każdego z nich występuje oryginalny zapis graficzny, który charakteryzuje zmienność kroju i wielkości czcionki, eksponowanie pojedynczych wyrazów, rozplanowany układ nieregularnych mas słownych na stronie, sporadycznie dwukolumnowy zapis. Także treść utworów Millera i Beauduina jest podobna. Dominuje w nich tematyka urbanizacyjna, istotnym zagadnieniem staje się sytuacja człowieka postawionego wobec natłoku zjawisk miejskich i ludzkich mas. U francuskiego poety bohater odnajduje swoje miejsce w „paroksyzmie materii”, identyfikuje się z miastem

sansowe szkice, zob. J. Bajda Młodopolska poezja wizualna, w: tejże Poeci - to sq̨ słów malarze... Typy relacji między słowem a obrazem w książkach poetyckich okresu Młodej Polski, Wydawnictwo UWr, Wrocław 2010, s. 371-382; także: S. Sobieraj Wizualność w polskiej poezji międzywojennej, w: tegoż Awangarda mniej znana, Wydawnictwo Naukowe UPH w Siedlcach, Siedlce 2018, S. 128-144. 
jako synekdochą świata, odkrywa „wielkie prawo równowagi" ${ }^{40}$. Natomiast w Zielonym koncercie Millera podmiot liryczny mniej optymistycznie opisuje relacje między sobą a tłumem:

na moją twarz

faliście płyną

ultrafioletowe promienie mrówczych przedziwnych zabiegów

echa strudzonych pulsów transmisji

spojrzenia głodnych wydętych zawiści

krótkie przebłyski tajemnic ulicy

gdzie z daleka z tamtego brzegu

masy idące dalekie masy

idą w promieniach ultrafioletowych

skąd idzie moja twarz?

tajemnice ulicy

tną transmisyjnie

dziwnie zabiegi dziwnych obcych ludzi

$[\ldots]$

burzliwie kwitnie sygnałami zieleń

burzliwa zieleń spiętrzonych fal

$\mathrm{z}$ rotacyjnej maszyny

spadło jedno słowo

spadło jedno słowo

\section{$\mathrm{MY}^{41}$}

Siła masy ludzkiej, tutaj ekspresyjnie dookreślonej za pomocą dźwiękonaśladowczego zestawienia "tumult tłumu", a także jej wpływ na jednostkę są ukazane poprzez powtórzenia słowa "MY" i czasowników w pierwszej osobie liczby mnogiej. Tłum to świat zewnętrzny, świat innych ludzi, innych poglądów. Budzi on niepokój podmiotu, który kilkakrotnie stawia znaki zapytania obok zaimka osobowego ,ja”, wreszcie przeciwstawia swoje „JA" - wielkiemu

\footnotetext{
40 N. Beauduin Miasto we mnie, przeł. W. Melcer-Rutkowska, "Blok” 1924 nr 3/4, S. 2.

E. Miller Zielony koncert, "Blok" 1924 nr 3-4, s. 14.
} 
"MY" (ważność tych sił jest podkreślona zastosowaniem majuskuły w zapisie), wierząc, że po wchłonięciu tego, co nazywa „wy”, pozostanie wciąż niezależny: „JA - wykrzyknik" "2. Finalny fragment utworu, opisujący nadejście „zielonej fali", daje podpowiedź w kwestii eksplikacji tytułu. Byłby zatem „zielony koncert” pieśnią wolności jednostki, ale też pieśnią radości (życia) głoszoną z powodu wyzbycia się ograniczeń i konformizmu, narzucanych przez społeczne prawo większości ${ }^{43}$.

Erotyk Stara historia zawiera jeszcze więcej udziwnień graficznych niż analizowany wyżej wiersz. Oprócz zróżnicowania czcionki występują liczby pisane w skośnej orientacji wznoszącej oraz wpisana w prostokąt enklawa słowna ${ }^{44}$, która imituje wiadomość w postaci miłosnego biletu:

\section{Allanie - \\ dziśo 7 wieczorem \\ będziesz ze mna w raju}

\section{Blanka. ${ }^{45}$}

W utworze, przypominającym mikroscenariusz filmowy - idea sketch albo treatment ${ }^{46}, \mathrm{w}$ którym brakuje jednak komentarza scenarzysty i kwestii dialogowych, sceny następują szybko po sobie jak w kinematografie. Szkicowe uporządkowanie wyznaczają w tym wypadku incydentalnie i celowo wprowadzone kropki i przecinki, także szeregi rzeczowników. To wyjątkowa sytuacja w tekstach Millera, zapisywanych konsekwentnie - zgodnie z regułami futurystów - wierszem wolnym i bez użycia interpunkcji. Oto przykład filmowej wyobraźni warszawskiego artysty:

42 Tamże.

43 Inaczej interpretuje wiersz Paweł Graf, odczytując w jego treści przede wszystkim "dialog z koncepcją Marinettiego", który odrzucał rozum (na rzecz intuicji) oraz "psychologię ja”. Według badacza "tekstowe uwolnienie słów z niewoli składni" wyzwala w utworze moc jednostki. Zob. P. Graf Automobil w pędzie. Studia o futuryzmie i futurystach, Wydawnictwo Naukowe UAM, Poznań 2018, s. 443-444.

44 Takie zabiegi pojawiły się najpierw w twórczości Tytusa Czyżewskiego. Później pomysł z "graficzną wizualizacją plakatu" wprowadził do wiersza Cukier krzepi Edward Szymański. Zob. S. Sobieraj Retoryka rewolucji i awangardowy sztafaż w wierszach Edwarda Szymańskiego, w: tegoż Awangarda mniej znana..., s. 241.

E. Miller Stara historia, "Blok” $1924 \mathrm{nr} 3 / 4$, s. 7. 
Mętny blask latarni. Jest pusto. Wychodzi z bramy. Ona. Deszcz mży sentymentalnie. Mały dobosz wandejski staje wyprostowany przed nią, wybija gwałtowny, tryumfalny werbel niech żyje królewna!

Ona

rzuca mu białe kwiaty

i i i

kwitną pomarańcze

pędzą auta

gasną latarnie

na półce księgarskiej leży melancholijny poemat

O PLĄTLIWYM WŁOSIE W LESIE

gdzieżeś się podziała?47

W przywołanych wierszach Millera widać planowe rozmieszczenie na stronie mas słownych. Znowu trop wiedzie do Beaduina, którego inspiracja w tym wypadku ma jeszcze inne niż wyżej wskazane uzasadnienie. Otóż, Tadeusz Peiper w 1923 roku opublikował w swoim tłumaczeniu wypowiedź teoretyczną francuskiego pisarza, która objaśniała tego rodzaju praktyki, dając definicję poematu synoptycznego ${ }^{48}$. Mowa była tutaj o trójplanowości tekstu, który mają scalać plany: fizyczny, intelektualny i intuicyjny. Ponadto w zakresie tych planów powinny znaleźć się elementy psychiczne, rytmiczne i ewokacyjne, a zasadą grupowania słów miała być analogia dźwiękowa. Beauduin podkreślał znaczenie nowoczesnych sztuk wizualnych, tj. plakatu i kina, dla techniki poetyckiej ${ }^{49}$.

Nowatorskie teksty autora Fikcyjnej postaci wykorzystują typografię w sposób sfunkcjonalizowany. Odmienny wygląd graficzny poszczególnych elementów utworu oraz przesunięcia i rozsunięcia grup werbalnych służą zaznaczeniu dodatkowych w zestawieniu z tradycyjną metodą druku semantycznych aspektów komunikatu poetyckiego, wydzieleniu wątków tematycznych i narracyjnych bądź najbardziej istotnych kwestii. $\mathrm{O}$ ile w innowacjach wizualnych stosowanych przez Sterna wyrażał się ludyczny trend w sztuce, spokrewniony z pomysłami dadaistów, a w poezjografii Czyżewskiego niemałą rolę odgrywała wyobraźnia malarska tego twórcy, o tyle Miller używał

E. Miller Stara historia..., s. 7 .

N. Beauduin O potrzebie nowej techniki poetyckiej. Poemat synoptyczny, poemat wieloplanowy, przeł. T. Peiper, "Zwrotnica" $1923 \mathrm{nr}$ 4, s. 108-109. 
podobnych środków wyrazu ikonicznego, ale w wymiarze systemowym, konsekwentnie powtarzając niektóre chwyty „montażowe” w określonych częściach dwukodowej kompozycji.

Wspomniana systemowość wskazuje na analogie z niewiele później opisanym i wprowadzonym do praktyki przez Szczukę ${ }^{50}$ i Strzemińskiego ${ }^{51}$ drukiem funkcjonalnym, co skutkowało współpracą wspomnianych artystów plastyków z poetami kręgu „Zwrotnicy” i „Almanachu Nowej Sztuki”. W numerze 5. "Bloku” redaktorzy, Teresa Żarnowerówna i Mieczysław Szczuka, ogłosili miniartykuł programowy, który był zaczątkiem konstruktywistycznego przewrotu w relacjach między sztukami plastycznymi i literaturą. Pisano w nim o „użyciu różnego rodzaju czcionek”, znaczeniu kierunku druku oraz „bogactwie środków i kontrastów graficznych”, co miało dać w efekcie: „ekonomiczne wyzyskanie miejsca" oraz zwiększenie zainteresowania wśród czytelników ${ }^{52}$.

Edmund Miller również miał na uwadze zasadę ekonomii w sztuce, którą odnosił do drukarstwa - „gdzie ekonomia przejawia się jako czynnik pracy twórczej"53. Jako że opublikował swoje teksty poetyckie przed najważniejszymi deklaracjami towarzyszy z „Bloku”, można postawić tezę, że był pionierem druku funkcjonalnego w liryce polskiej. Stał się pierwszym i jedynym poetą konstruktywistą u nas, bowiem w przeciwieństwie do Szczuki i Strzemińskiego, graficzne opracowanie stosował we własnych wierszach. Cechuje je przede wszystkim świadome konstruowanie poetyckiej materii z określonych elementów, czyli w tym wypadku z grup słownych ujętych w kształt wizualny, zakreślony zadrukowaniem części strony bądź wyróżniony typograficznie. Utwory te, przekraczając zasadę linearności, stają się swoistymi „instalacjami”, w których pojawiają się sugestie różnych porządków lektury ${ }^{54}$, np. horyzontalnego i wertykalnego. Wyeksponowane w nich graficznie zapisy zawierają dodatkową wartość semantyczną.

Mieczysław Szczuka projektował okładki i typografię w niektórych zbiorach wierszy Brunona Jasieńskiego i Anatola Sterna. Zob. S. Wysłouch Literatura a sztuki wizualne, PWN, Warszawa 1994 , s. 52. niu z poetą wprowadzał zmiany segmentacji tekstu, stosował zróżnicowane czcionki itp. Por. S. Wysłouch Literatura a sztuki wizualne, s. 46-58. Red. [T. Żarnowerówna, M. Szczuka] Drukarstwo. O układzie graficznym, "Blok” 1924 nr 5, s. 11. E. Miller Rola ekonomii w twórczości, "Blok” 1924 nr 3/4, s. 10. K. Skibski Tabularność wiersza wolnego i jego konsekwencje lekturowe, „Poznańskie Studia Polonistyczne. Seria Językoznawcza" 2013 t. 20, z. 1, s. 79-80. 
Wspomniany konstruktywizm jest punktem dojścia o rodowodzie częściowo futurystycznym ${ }^{55}$. Być może to futuryzm był najbliższy Millerowi w jego poszukiwaniach nowych form wyrazu, a co za tym idzie - w eksperymentach poetyckich. Publikowany już po jego odejściu z redakcji „Bloku” wiersz nie jest tak rewolucyjny pod względem formalnym jak wcześniejsze, brakuje w nim aspektów graficzno-wizualnych. Paryżw nocy to pejzażowy obraz francuskiej metropolii, zarysowany za pomocą dwudziestu jeden krótkich wersów, których układ naśladuje jakby szybki oddech i mówienie w pośpiechu, czyli rytm wielkomiejskiego życia:

\author{
światła \\ świateł bez końca \\ noc się budzi \\ dzień bez słońca \\ tłum ludzi \\ samochody \\ bez liczby bez miary \\ gwar wrzawa \\ pełne bulwary \\ łuna krwawa \\ na górze wysoko \\ szał elektryczności \\ ruch męczy oko \\ wciąż przewijają \\ ostatnie nowości \\ barwy zmieniają \\ głoszą światu \\ tumult mas \\ ... stanął czas \\ stanęły zegary \\ Ruch - rozmach bez miary ${ }^{56}$
}

55 Zdaniem Krzysztofa Jaworskiego wierszom Millera blisko do fonetycznych i optofonetycznych utworów dadaistów (K. Jaworski Katalog wystawy..., s. 123). Trudno się z tą opinią w pełni zgodzić. Uwagę powyższą można odnieść jedynie do tekstu „RLIR...", co znajduje wyraz również w moich analizach. 
W wierszu porządek dyktuje rytm wyliczania i powtórzeń, jak również gęsto usiane rymy, podkreślające nastrój zagrożenia cywilizacyjnego. Uczucia anonimowego podmiotu są stonowane, ale konstytucja świata przedstawionego, w którym domeną życia staje się noc, wszechobecny ruch „męczy oko” i prowadzi do zatrzymania czasu, może budzić niepokój. Brakuje tu fascynacji urbanizmem i maszynizmem, chociaż pozostają oddźwięki futurystycznej spontaniczności i oszczędności słów (np. w pierwszej części tekstu prawie wcale nie występują czasowniki w formie osobowej).

Niestety, nie zachowały się inne publikacje twórczości lirycznej tego autora. Najprawdopodobniej porzucił ją całkowicie po zerwaniu kontaktu z konstruktywistami i sztuką awangardową na rzecz działalności publicystycznej i prozatorskiej.

Nie ulega wątpliwości, że futurystyczno-konstruktywistyczne tendencje wizualne w poezji polskiej rozwijały się i później. Nierzadko były kontynuacją eksperymentów i doświadczeń wczesnego okresu nowej sztuki, w czym miał również swój udział Edmund Miller. Nieobce były one Tadeuszowi Peiperowi, Janowi Brzękowskiemu i Marii Pawlikowskiej-Jasnorzewskiej, a wiodły m.in. w stronę współczesnej poezji konkretnej Stanisława Dróżdża i Mariana Grześczaka czy też innego rodzaju słowno-wizualnych praktyk Jacka Durskiego.

\section{Abstract}

\section{Sławomir Sobieraj}

SIEDLCE UNIVERSITY OF NATURAL SCIENCES AND HUMANITIES

Edmund Miller's Experimental Poetry: Between Futurism and Constructivism

Sobieraj focuses on the figure of Edmund Miller, a forgotten writer and poet of the interwar period (1920s-1939), presenting his creative life in relation to his cooperation with Polish constructivist artists. Miller's poetry, though scarcely preserved, is read in the context of artistic trends such as Futurism, Constructivism and Dadaism. Sobieraj draws attention to the poems' experimental form, their graphic innovation and connection to visual poetry.

\section{Keywords}

Edmund Miller, Futurism, Constructivism, Dadaism, visual poetry 